\title{
Reconstructing Faith: Religious Overcoming in Dewey's Pragmatism
}

OF THE THREE CLASSICAL AMERICAN PHILOSOPHERS treated in this book, John Dewey is the most expressly antagonistic toward the hold religion has on the expectations surrounding human transformation. The roots of this antagonism are philosophically and psychologically complex. Stephen Rockefeller and others have shown that Dewey's religious attitude permeates much of his professional philosophical work even though he says that his own religious understanding did not constitute a "leading philosophical problem" for him (Later Works [LW] 5:149-150). Reading A Common Faith, though, challenges this dismissal. If religion is not a leading philosophical problem for Dewey, overcoming religion is. In this way, $A$ Common Faith is one of Dewey's most important and revealing philosophical texts.

A Common Faith inadvertently caps Dewey's philosophical career. Rather than put religion in its place, though, $A$ Common Faith has done more to put Dewey in his place in relation to religion than vice versa. This raises the question of why Dewey could not overcome religion in the way he intended. Is the religious overcoming that Dewey suggests possible? Does pragmatism stand or fall on the question of overcoming religion? It is clear that Dewey pursues the authority of religious life in order to capture that vitality for his progressivism and to demonstrate that the deepest human values emerge from within experience. ${ }^{2}$ Recovering religious power for pragmatism is a confessional task for Dewey, and his passion is evident in his concern "that what is genuinely religious will undergo an emancipation when it is relieved from [the encumbrances of religion]; that, then, for the first time, the religious aspect of experience will be free to develop freely on its own account" (LW 9:4). Dewey longs for the sense of this "free" development of the religious attitude, which is possible only through overcoming "religion" and its false authority. Dewey's confessional challenge is to describe the transformation of common expectations in such a way that men and 
women are able to abide where there is no middle ground between the religious attitude and religions. This is no bloodless philosophical work, however. Dewey writes to restore and secure religious faith for the men and women who construct the community through reflective action and relationships. This is Dewey's express intention. The only possible ground to criticize $A$ Common Faith substantially emerges in terms of this personal transformation-from religion to the religious attitude, but also from no-faith to faith.

My plan in this chapter is to follow the structure of the three essays that comprise $A$ Common Faith. In the first section, I examine Dewey's notion of the transformation to the religious attitude in "Religion versus the Religious." Conversion from religion to the religious attitude is the overcoming Dewey thinks is necessary for the democratic community to thrive. Transcending the content of present practice, though, requires an adequate ground for criticism. In the second section, I focus on the content aspects of "Faith and Its Object" that makes this critical advance possible. Dewey wants to stabilize the sources of authority in human practice to enhance the products and consciousness of intelligent control. In the third section, I follow Dewey's ascending polemic against the supernatural in "The Human Abode of the Religious Function." Conversion completes Dewey's thought here in the sense that the religious function is necessary to produce a material effect on practice that manifests intelligent control of the sources of authority in common life. The only material effect that would sufficiently demonstrate this control is the explicit overcoming of supernatural religion. If supernatural dependence is not overcome, Dewey has no ground to claim that the democratic community is secure. I conclude with a critical evaluation of Dewey's attempt to reconstruct faith as the religious overcoming implicit in the growth of the democratic community.

\section{The Religious Attitude}

It is the claim of religions that they effect this generic and enduring change in attitude. I should like to turn the statement around and say that whenever this change takes place there is a definitely religious attitude. (LW 9:13)

On its face, Dewey's interest in the religious attitude constitutes a sort of victory for people who refuse to accede to absolute naturalism. Dewey 
describes an enduring change of a person's attitude to the spirit or sense of the world beyond what can be accounted by material interaction. $\mathrm{He}$ establishes a common ground with ordinary religious expectations that is crucial for all that follows in $A$ Common Faith. In this section I will focus on the image of personal conversion as the common ground that Dewey establishes between himself and traditional religions.

Despite Dewey's interest in establishing common ground, the polemic character of $A$ Common Faith is evident in the quotation above. Dewey begins his analysis by unsettling the proprietary claim of religion(s) over the religious attitude. Making the distinction between "religion" and "the religious" this way quickly puts Dewey between two camps. On one hand, such a distinction challenges naturalism's rejection of the products or ground of religion. On the other hand, traditional believers are challenged to reexamine the moorings of their faith and to face Socrates' question from the Euthyphro: Is the holy what is loved by the gods, or is what is loved by the gods holy? Does religion know the true nature of its practice? Does a love of religion produce the good of religious life, or does the love of the good in religious life produce religion? In both ways Dewey's question leads to the opening of the ground for an understanding of "religious faith" that moves past the easy affirmation of traditional religion and past the easy rejection of naturalism.

Another aspect of Dewey's polemical beginning is less obvious. Dewey must argue that the religious overcoming he proposes is a reformation that arises internally in the self-conscious understanding of religion and equally internally in the communal desire for ideal action. The "religious attitude" must describe a growth intrinsic to religion that in effect cancels that religion. For if "religion" becomes a limit to growth, even a potential limit, at some level emergent value is subordinated to a prior value. In the same way, the "religious attitude" must describe the pressure intrinsic within human action for a fully conscious sense of ideal action. For if there is no opening within action for an unlimited transcendence in terms of the meaning of action, not just its temporal effects, then that too stands as an antecedent limit. The religious attitude gives Dewey a platform to argue against two forms of reification-first, that "God" stands as the ultimate telos for all religious value, and second, that the goal of action is the totality of material interactions.

Religion, however, is Dewey's concrete starting point. Dewey uses religion's dependence on supernatural beliefs as a foil in the first sentences of 
A Common Faith to move into an evaluation of authority that subtends all practice. From his description of the change to the "religious attitude," we will see that he is contending mostly with the authority of his own Christian background. Dewey's childhood connection to the Congregational church and his mother's Christian influence shows a deep but unquiet relationship. Robert Roth notes Dewey's adolescent involvement with his church in Vermont and Mrs. Dewey's integration of social concerns with her faith, although her son appears to have left these beliefs soon after leaving for Johns Hopkins. ${ }^{3}$ What beliefs Dewey held and when they were completely left is an open question, ${ }^{4}$ but in his early career Dewey combined his Christian view with the Hegelian conviction that human meaning is completely expressed in its social form. In his 1893 essay "Christianity and Democracy" he writes,

The significance of democracy as revelation is that it enables us to get truths in a natural, every-day and practical sense which otherwise could be grasped only in a somewhat unnatural or sentimental sense. I assume that democracy is a spiritual fact and not a mere piece of governmental machinery. If there is no God, no law, no truth in the Universe, or if this God is an absentee God, not actually working, then no social organization has any spiritual meaning. If God is, as Christ taught, at the root of life, incarnate in man, then democracy has a spiritual meaning which it behooves us not to pass by. Democracy is freedom. If truth is at the bottom of things, freedom means giving this truth a chance to show itself, a chance to well up from the depths. Democracy, as freedom, means the loosening of bonds, the wearing away of restrictions, the breaking down of barriers, of middle walls, of partitions. (Early Works [EW] 4:8)

Despite the passion in these words, Dewey experienced a remarkable change of mind that resulted in his leaving both Hegel and Christianity. This dramatic shift coincides with his move from Michigan to Chicago in $1894 .{ }^{5}$ With this change of place, Dewey turns to the natural dimensions of human initiative for transformation. He explores the ways the social expression of human reality breaks beyond what any religion can anticipate or hold and beyond the security any ideal can represent. The church is a finite institution, both in terms of the limit of its membership due to its peculiar intellectual beliefs, and finite in terms of its ability to extend its method of taking new habits and transforming itself. An infinite community, like democracy, avoids these limitations. In Human Nature and Conduct Dewey speaks to this vision of democracy: 
Democracy as compared with other ways of life is the sole way of living which believes wholeheartedly in the process of experience as end and as means; as that which is capable of generating the science which is the sole dependable authority for the direction of further experience and which releases emotions, needs and desires so as to call into being the things that have not existed in the past. (LW 14:229)

The change in Dewey's thinking between these two conceptions of democracy is significant on several levels. In the first passage, Dewey claims that God's work gives meaning to democracy. The removal of barriers is Christ's immanent work in the world, and so democracy is the evolving reality of that "spiritual" meaning in our practice. Democracy depends on God's authority for its meaning. In the second passage, democracy needs no warrant for its meaning because it is the "sole way of living" in proper relation to the process of experience. This warrant is based on the singularity of the character of democracy. This claim makes an interesting parallel to the charge of exclusivism Dewey lays at the feet of religion later in A Common Faith. Further, his reference to science exercising its authority to "call into being things that have not existed" is the counterpoise to John's words concerning Jesus that "not one thing came into being except through him" (John 1:3, New Jerusalem Bible). The dialectic between religion and democracy runs into the deepest senses of valuation Dewey can describe. There may be no more meaningful dyad for Dewey than religion and democracy.

Based on these two conceptions of democracy we can see that Dewey's struggle points to the competing authorities of science and God. The confusion in A Common Faith is not principally that of the reader. The confusion is a reflection of Dewey's strained effort to achieve a middle ground between these conceptions as he sorts out the ground of his faith into that which makes democracy possible. But this ground only arises in the contest over authoritative power. Moving from God to science as the authority implicit in human action is the question at hand, and the polemic character of $A$ Common Faith shows this aspect of Dewey's own overcoming was not yet settled. Further, Dewey's claim that the reformation of religion into the religious attitude is a matter of internal progression, independent of a "special" religious experience or a prompt by a transcendent God, also means that the polemic investing $A$ Common Faith is an image of Dewey's divided thinking. The combination of an internal progression related to determining the authority over 
practice is leading Dewey to the constructive role of conversion in discovering the religious attitude, but there is also an aspect of defensiveness in this development.

Dewey's ability to move through the internal challenge of religion responds to Reinhold Niebuhr's criticism of Dewey's progressivism in the opening pages of Moral Man and Immoral Society. ${ }^{6}$ For Niebuhr, the ability to choose in anything like "freedom" would be possible only if an individual could act against the society:

Defiance of a community, which is in control not only of the police power but of the potent force of public approval and disapproval, in the name of the community, which exists only in the moral imagination of the individual and has no means of exerting pressure on him, obviously points to a force of conscience more individual than social. . . . Most individuals lack the intellectual penetration to form independent judgments and therefore accept the moral opinions of their society. ${ }^{7}$

For Niebuhr, then, standing at a critical difference from the prevailing authority of the community is the issue. Individuals, by and large, cannot oppose their own grasp on authority to that of the larger society. Social change depends on an institutional power wielding an authority sufficient to challenge the authority of the community.

In light of this kind of critique, we can appreciate the significance of Dewey's trust in a conversion-like change of perspective concerning authority. Dewey does not dispute the power of social thinking, but he thinks the hope of merging everyday life into an ideal form grips the individual in a way no community can challenge. Dewey's faith is built on the cornerstone "that the reverence shown by a free and self-respecting human being is better than the servile obedience rendered to an arbitrary power by frightened men" (LW 9:7). No person needs instruction to see this "better," and no power of a community or other construct can diminish this "better" of freedom. From this ground of self-respect Dewey dismisses God-not from a metaphysical challenge to the idea of God, or even in opposition to an abductive argument like Peirce constructs-but considering human growth as a universally available good, freedom from an unchosen supervening authority and the choice to an appearing authority clears up the picture. Since we are able to choose even the authority that we serve, the issue of human progress escapes the bounds Niebuhr describes. All that is needed is for Dewey to say how this choice of authority works. 
The question of authority is of central importance for Dewey, for he knows that the spiritual meaning of the democratic community depends on this answer. His task is to describe the critical appropriation of authority that is a product of freedom and that is also sufficient to overcome the Niebuhrean criticism that such a choice is a delusion. A chosen authority would make an internal reform of the individual possible that counteracts the movement of institutions and society despite the apparent imbalance of power. Dewey describes a kind of conversion, then, that is the adjustment of the self into a "unity" in light of an appearing authority that provides a sense of power within his philosophical program.

\section{CONVERSION}

I am using conversion here in a limited way. I mean to indicate Dewey's sense that individuals are able to attain a separation from a way of being in the world that is devoid of its highest potential value. This internal transformation must be brought into clear view in order to make the arguments in $A$ Common Faith cohere. Without this transformation, Dewey fails to address the mode of becoming in the practical lives of men and women of faith. The religious attitude involves a dramatic transformation of the person, although not necessarily an immediate one.

[The religious attitude] demands that in imagination we wipe the slate clean and start afresh by asking what would be the idea of the unseen, of the manner of its control over us and the ways in which reverence and obedience would be manifested, if whatever is basically religious in experience had the opportunity to express itself free from all historical encumbrances. (LW 9:6)

This suggestion of "obedience to the unseen" might send shivers down the spines of his naturalist companions, as would the claim that we recognize "its control over us." Dewey is surprisingly close to Edwards's conception of conversion, since both reject the possibility of an interjection of special knowledge or the need for an institutional form of transformation. Dewey is especially close to Edwards in his reference to the religious attitude as a settled transformation of the will that affects an orientation evident in all of a person's habits.

But there are also changes in ourselves in relation to the world in which we live that are much more inclusive and deep seated. They relate not to 
this or that want in relation to this or that condition of our surrounding, but pertain to our being in its entirety. Because of their scope, this modification of ourselves is enduring. . . There is a composing and harmonizing of the various elements of our being such that, in spite of changes on the special conditions that surround us, these conditions are also arranged, settled, in relation to us. This attitude includes a note of submission. But it is voluntary, not externally imposed; and as voluntary it is something more than a mere Stoical resolution to endure unperturbed throughout the buffetings of fortune. It is more outgoing, more ready and glad, than the latter attitude, and it is more active than the former. And in calling it voluntary, it is not meant that it depends on a particular resolve or volition. It is a change of will conceived as the organic plenitude of our being, rather than any special change in our will. (LW 9:12-13)

The experience that culminates in this change of will to the religious attitude is not Dewey's focus in the text in hand. What is striking is that Dewey leaves out any positive contribution traditional religion has for this change. Whatever does bring it about is religious in effect, but what this is remains vague. Dewey's focus is the change of attitude, and dislocating this change from a necessary relationship to a religion works the reversal of origin on which his entire argument turns.

Dewey admits that conversion of the will has been most apparent within particular religious traditions, although he turns this into the critique that this power has been captured and pressed into service as the means of supporting supernatural beliefs. Thus, the power of religious transformation is withheld from the activities from which it genuinely emerges and for which is it most beneficial. There are two claims here. First is that the difference of the religious attitude in the lives of men and women is only coincidentally associated with religions and the supernatural ground of religion. The second claim is that revealing the falseness of beliefs that encumber the power of religious transformation is the reflective task of the philosopher. Persons stuck within "cultural accretions" of religion may not be able to see this lost good, and so the critical attitude of the philosopher is essential to bring these encumbrances to light.

The most direct opposition to the traditional understanding of religious conversion centers on the origin of religious transformation. Dewey offers only one argument here. Imaginative ideals, not the reproduced images or icons of a tradition, are the guide for refining and extending practice. Imaginative ideals are the basis for the expansion of daily experience, and there is no internal limit to the reach of this power 
of imagining better things or richer experience. There is a difference, however, between the imagination necessary for the religious attitude and imagination concerned with routine activities. In the religious sense imagination stands apart from the day to day activity in order to construct a holistic ideal of the self. Dewey says that the religious attitude results from an interpenetration of imagination in all elements of our being; "The idea of a whole, whether of the whole personal being or of the world, is an imaginative, not a literal idea. The limited world of our observation and reflection becomes the Universe only through imaginative extension. . . . Neither observation, thought, nor practical activity can attain that complete unification of the self which is called a whole" (LW 9:14). The imaginative extension of the whole personal being is an ordering ideal, such that we are "conquered, vanquished in our active nature by an ideal end; it signifies acknowledgment of its rightful claim over our desires and purposes. Such acknowledgment is practical not primarily intellectual. It goes beyond evidence that can be presented to any possible observer. . . [S] uch moral faith is not easy. It was questioned whether the Son of Man in his coming should find faith on the earth at his coming" (LW 9:16).

I have shown the repetition of Dewey's emphasis that the imaginative leap that produces the religious attitude is not a matter of observation or intellectual grasping. This ideal whole emerges only in the imaginative reconstruction of practice that incorporates all aspects of practice but that is never exhausted in practice. "Religious will," Dewey says in his Psychology, "is conscious realization that [the ideal and real will] are one because man is a self-determining power. It is the realization that a perfect will is reality. It is the realization of freedom through the realization of the union of finite and the infinite Personality. It is only when we recognize this latter activity of will that we are able really to comprehend the previous forms of activity" (EW 2:362). The power of self-determination is brought into view only through the exercise of a holistic image of life that has a "rightful claim over us." This reflects the tone of Augustine's appeal to God, "command what you will, give what you command," in that Dewey's view of the holism of our being is an active engagement with a compelling authority, not the reflective accomplishment of a belief in an antecedent reality.

Parsing out the meaning of the "rightful claim" that exercises vanquishing power over our practical lives, and yet has its origin in the imaginative 
extension of our own ends, is the puzzle of Dewey's religious attitude. I do not think Dewey thinks it is wise to dwell on this question too long, as his response to Wieman's and Hartshorne's debate over the question of his theism dragged on. This debate is less important than the fruit that results from the lives of reoriented purpose that are able to endure the turns of fate and the frustrations of failure because of this settled change of will. The common use of "God" to refer to this aspect of human life did not bother Dewey, and his desire to speak in a way that connects to this hope in everyday life further supports his use of the term. ${ }^{8}$

I want to follow through with Dewey's notion that the religious attitude yields a "genuine perspective" of the ends of life that becomes a stable platform for pursuing the work of growing human life in richness. From this platform, Dewey remakes his criticism against traditional religion as promulgating an end of human life that is not with us. In his view, traditional religion calls its adherents to produce what they cannot control, and this is what makes religion an occasion for fear. The end expected from our practice does not, indeed cannot, arise from us. In the remaining sections of $A$ Common Faith Dewey takes aim at these fears, first to show that the proper and ultimate end of human life arises organically within that life, and then to show that the anticipated judgment should not occasion the fear of coming up short in terms of a nonhuman criterion, but should occasion widespread dedication and fervor for proving the growth of richness in action for the future judgment of our own community.

\section{Stabilizing the Religious Attitude with the Object of Faith}

The positive lesson is that religious qualities and values if they are real at all are not bound up with any single item of intellectual assent, not even that of the existence of the God of theism; and that, under existing conditions, the religious function in experience can be emancipated only through surrender of the whole notion of special truths that are religious by their own nature, together with the idea of peculiar avenues of access to such truths. For were we to admit that there is but one method for ascertaining fact and truth-that conveyed by the word "scientific" in its most general and generous sense-no discovery in any branch of knowledge and inquiry could then disturb the faith that is religious. I should describe this faith as the unification of the self through allegiance to 
inclusive ideal ends, which imagination presents to us and to which the human will responds as worthy of controlling our desires and choices. (LW 9:23)

The first essay of $A$ Common Faith carves out the common ground of transformation to the religious attitude. The second essay, "Faith and Its Object," establishes the content that makes such a transformation possible. Dewey's concern for a ground of faith free from disruption is important to note, as is his dependence on imagination to discover ideal ends that sponsor a unification of the self. Working these two concerns together, security from disruptions and the imaginative ground of ideal ends, sets Dewey's notion of religious transformation on a path that leads to a complete rejection of the authority of religion. Here, in a sign of good faith, Dewey advises religion to surrender unconditionally to science.

There are two ways to proceed from this place. Dewey may be advocating a replacement of religion with a devotion to science, disconnected from any prior tradition strictly or loosely termed "religious." This negotiated surrender would in fact become a manifesto of a remarkable trade of "special truths" for general ones that need no evangelistic efforts for their promulgation. A second path takes Dewey in quite a different direction. This is the way of "science" generously understood, that is, so generously that it includes the ideal ends formerly known as "special truths" that are recast in their inclusive and ideal forms as those that have always and will continue to inspire human devotion. What is emancipated by this surrender is the religious person from the task of producing compendia of special truths and ever new methodologies for attaining those truths that have to endure and respond to scientific criticism. Dewey weaves between these two paths, speaking in some instances as a helpful friend and at other times as the most strident critic of religion. His basic commitment to reconstructing faith inspires him to dwell in the reflective space between reconstructing and deconstructing religion. Dwelling in this space means unveiling the authority that is most productive in terms of transforming the experience of the individual.

Dewey's faith is based on the confidence that the ultimate authority for transforming experience arises within the continuum of experience. Simply to be as a human means to be transforming experience, "constantly shaping ourselves to or modifying the environment with which we react," as Michael Eldridge puts it. ${ }^{9}$ But the quality or effect of transformation depends on the ends sought, and these reflect the attitudes 
and dispositions trained into the individual. Concretely influencing the attitudes on which transformation depends seems unlikely. Real reform, even of a person, is nearly impossible even through education. ${ }^{10}$ The mystery of personal change and transformation invests all of Dewey's philosophical musings and hopes. For this reason, conversion to the religious attitude becomes even more important as a sign of the character of human intelligence to seek the limits of action by an internal criticism.

Genuine transformation depends on a precarious authority. Unless the content to which we are transformed emerges from the process of transformation itself, the ideal with the practice, there is no intelligent control in transforming and shaping experience. This model of transformation cannot accommodate an ideal already in existence, because if an ideal is somehow already "out there" the transformative moment is a result ordered by some representation, and no transaction of mutual forming can arise in such a representation. It excludes intelligence. Conversion to the religious attitude is all that can at once be religious, in terms of approaching ideal ends, and also transformative, since there is no static image toward which it moves, no set completion that it seeks beyond its own control. Science is the process of moving toward this transformation that does not depend on the authority of an antecedent ideal. But Dewey has yet to show how these scientific beliefs become suitable for a platform for the transformation to a religious attitude.

Dewey's way between these two positions-religion that becomes scientific and science that becomes religious-is the true test of the "object" of his faith. On the one hand, he suggests that religious truths and facts of doctrine must be considered symbolically; "they are symbolic of the reality of ends moving us in many forms of experience. The ideal values that are thus symbolized also mark human experience in science and art and the various modes of human association" (LW 9:29). Only in this way can the mode of access to these truths be open to all who obey the structure of inquiry. On the other hand, Dewey's argument also depends on scientific inquiry finding its limit in these "ideal values" common to religious faith. I think this aspect of Dewey's pragmatic inquiry is often overlooked because it requires an inference from scientific inquiry back to religious power. It requires, for instance, the scientific inquirer to seek the ground of the "unity" on which the authority of constructing beliefs stands. This is the needed criticism that religious thinking brings to scientific intelligence that makes it a possible 
instrument of human transformation. Discovering this potency of ideal ends within the continuum of transforming experience is synonymous with the development of communication.

Communication is Dewey's broadest conception of the human impulse to reconstruct experience. The religious character of emergent communication in Experience and Nature inspires Walter Kaufmann to point to Dewey in the introduction to his translation of Martin Buber's $I$ and Thou, although he says that Buber is far better in "endowing the social sphere with a religious dimension."11 Allegiance to ideal ends emerges in communication that enables the whole person to stand in relation to another. The origin of this wholeness in the natural emergence of communication is Dewey's clearest deviation from Hegel, since communication itself becomes the ground of the distinction between the ideal and the material. Rockefeller associates Dewey's immanentism to Feuerbach, but Dewey differs from this inverted idealism in the sense that every experience is an opening for transformation that may have transcendentally effective results on future experience. ${ }^{12}$ Some facts have more potentially pervasive effects than others, but none are limited.

Essence is never existence, and yet it is the essence, the distilled import, of existence; the significant thing about it, its intellectual voucher, the means of inference and extensive transfer, and object of esthetic intuition. In it, feeling and understanding are one; the meaning of a thing is the sense it makes. (LW 1:144)

A fact or a word is not powerful by its existence, but through the inference and transfer of meaning that is possible through it. This distillation of a word to its extensive transfer is found only as its ideal form emerges in action. For instance, language makes description existent but the essence emerges as an ideal in making sense of some range of experience that exceeds the facts of observation. Language transforms experience because it is performative.

Language is always a form of action and in its instrumental use is always a means of concerted action for an end, while at the same time it finds in itself all the goods of its possible consequences. For there is no mode of action as fulfilling and as rewarding as is concerted consensus of action. It brings with it the sense of sharing and merging in a whole. Forms of language are unrivalled in ability to create this sense, at first with direct participation on the part of an audience; and then, as literary forms develop, through imaginative identification. (LW 1:144-145) 
A word opens to view the transformation of action into a possible consensus of action. This ideal of consensus extends beyond the present word through imagination to an ultimate word, an ultimate consensus of action. Religious language is an example of this imaginative consensus that seeks an ultimately incorporative word. Although religious language is not a compendium of "special truths" for Dewey, he recognizes its performative power for constructing communities. What is true of language in general is true of religious language in particular: "it becomes a word by gaining meaning; and it gains meaning when its use establishes a genuine community of action" (LW 1:145).

The community of action religious language constructs, however, is not bent on realizing a concrete union of divine and human existents. It is bent on realizing the union of actual and ideal practice as a method of extending the consensus of transformative action. The religious nature of language is a reflection of its authority to develop ultimately comprehensive ideals in action. Here Dewey moves directly against Hegel. While accepting the conclusion that the ultimately real is the social realization of human life, Dewey holds that the development of this real is contingent on the emerging authority of a method of producing an imaginative whole in human action. This movement in action has the method of discovering authority for consensus as its content. "For a perceived mode of becoming," Dewey says, "is always ready to be translated into a method of production and direction" (LW 1:183).

The power of religious language follows from the awareness that it is continuous with a method of establishing the authority of ideal ends. This is the sense of Dewey's suggestion about religious beliefs and terms in "Faith and Its Object."

What would be lost if it were also admitted that they have authoritative claim upon conduct just because they are ideal? The assumption that these objects of religion exist already in some realm of Being seems to add nothing to their force, while it weakens their claim over us as ideals, in so far as it bases that claim upon matters that are intellectually dubious. The question narrows itself to this: Are the ideals that move us genuinely ideal or are they ideal only in contrast with our present estate? (LW 9:29)

Dewey's deepest question in "Faith and Its Object" is how it is possible to test the genuineness of religious ideals. How is it possible, to say it a little differently, to bring religious ideals to the fiery crucible of practical 
evaluation of their effectiveness for transforming experience? Avoiding this test is precisely what traditional religion does that raises Dewey's concern.

What I have been objecting to, I repeat, is not the idea that ideals are linked with existence and that they themselves exist, through human embodiment, as forces, but the idea that their authority and value depend upon some prior complete embodiment ... where all facts and truths are already discovered and possessed, and all beauty is eternally displayed in actualized form. (LW 9:33)

Dewey is confident that his criticism of religion is helpful to its cause. Although "religion" has not yet secured its method of discovering the authority for its development, it continues to function based on the power of its language to construct communities of action performatively. This vitality and power can be improved by scientific criticism. Religion's openness to scientific critique and development is another sense of Dewey's "object of faith." The object of faith is to use all means to produce the integration of motive values and scientific confidence in practice. Religion's refusal to adopt the scientific method of establishing values puts it out of step with its desire to influence the practical lives of men and women. Conversion to the religious attitude discovers this lapse of method most effectively, as we will see in the next section.

What remains open and questionable concerning Dewey's object of faith, I think, is the origin of the impulse for the "whole" will. The discovery of the wholeness of will is different from the movement of authority in the development of practice. The sense of the whole person turns up from time to time in Dewey's thought as a casual reminder of something important but missing, and something that creates a host of problems. For instance, consider this statement from Human Nature and Conduct: "Each impulse is a demand for an object which will enable it to function. Denied an object in reality it tends to create one in fancy, as pathology shows" (Middle Works [MW] 14:98). Remembering the warnings of Jonathan Edwards concerning the genuineness of religious affections, it is fair to ask what the impulse for a whole will is, and how Dewey's story of communication escapes this hint of pathological fancy. If there is any strictly religious ground in Dewey, I think it concerns this sense of the wholeness of will and the genuineness of the impulse toward that wholeness. This is the third sense of the object of faith that I find in this chapter. From this third sense, it is possible to make a fair explanation of Dewey's notion of God. 
Dewey's religious faith in the wholeness of the person emerges in continuity with communication and the development of consciousness. Consciousness, Dewey says, "is an idea, is that phase of a system of meanings which at a given time is undergoing re-direction, transitive transformation" (LW 1:233). How one attains consciousness is bound up with this redirection and transitive transformation of experience. Wholeness must emerge with or because of a transformation that is holistic in its effect. For this to occur there cannot be an existent "other" from which we draw imagistic content, or an existent soul seeking to be clothed in action, or a metaphysical communion with God to which we are drawn to return, although this may be the closest metaphorically to what captures Dewey's imagination.

So far in this account we have respected Dewey's reluctance to generalize the will to power. There is only the inherent pressure of every activity of transformation to find an adequate manifestation. Dewey's argument for the wholeness of will is not based on an ascending development of transforming power. Rather, the wholeness of will is based on a search for an opportunity to use a power already existing. It mirrors Leibniz's proof for God: that this Being, if possible, must exist. So Dewey claims that human transformational consciousness, if possible, must become materialized in the wholeness of a personal will. The object of faith is this possibility of materialization.

Of course, Dewey's object of faith has a lot in common with a Christian object, namely the incarnation of God in Jesus Christ. But Dewey does not treat the similarities or differences between his incarnational model of intelligence and the incarnation of Christ, even in a wisdom sense that might avoid the problems of the historical Jesus. The absence of a consideration of Jesus Christ in "Faith and Its Object" follows, I think, because any mention of Christ might spark up Dewey's fear that he is in the neighborhood of transforming an essence into an existent. He could invoke "God" but not Christ, because the latter is fraught with an existential power that would compromise any scientific inquiry into that term. Faith is anticipatory action, and to be fully anticipatory it cannot give over its content to a prior term, even by allusion. This puts Dewey in an odd place. It is as if the revelation of Christ was essential for Dewey's religious understanding as a first term in realizing the limit of an ideal humanity, but then this term had to be forgotten in order to make this ideal limit forceful again in practice. Dewey has to 
become his own Christ in order to exercise anything like religious faith; he must be novel, purely reflective of the merging of ideal ends and actuality, and an unshakable incarnation of intelligence. Christ might not be mentioned in the text but this idea is still forceful even in its absence. The force of the Christological union is behind Dewey's compulsion to honor the union of ideal and actual: "It is this active relation between ideal and actual to which I would give the name "God"” (LW 9:34).

Whether one gives the name "God" to this union, operative in thought and action, is a matter for individual decision. But the function of such a working union of the ideal and actual seems to me to be identical with the force that has in fact been attached to the conception of God in all the religions that have a spiritual content; and a clear idea of that function seems to me urgently needed at the present time. (LW 9:35)

This notion of God, qualified even as it is, almost overwhelms Dewey. He must assert his intelligent power in determining his essence, for this is the true test of freedom. "God" stands for the imaginative coherence of the uncoerced union of the ideal and actual in our practice. Faith is the unlimited perspective of our responsibility for the creation of practice in accord with this ideal end, and, in a way, the creation of ourselves as the content to which experience and nature lead. Dedication to this faith is perceived in instances of scientific inquiry that are subordinated to the service of human freedom. ${ }^{13}$ Science, as a method, is complicit in achieving the end of controlled reflection, but science is subordinated to the power of an unlimited inquiry that alone expresses authority in the transformation of life. Dewey's faith is secure to the extent that whatever science discovers it cannot outrun the platform of transformation. It remains for the last essay of $A$ Common Faith for Dewey to say what this free creation of ourselves is for.

\section{Ideal Action and the Human Abode of the Religious Function}

The third stage would realize that in fact the values prized in those religions that have ideal elements are idealizations of things characteristic of natural association, which have then been projected into a supernatural realm for safe-keeping and sanction. Note the role of such terms as Father, Son, Bride, Fellowship and Communion in the vocabulary of Christianity, and note also the tendency, even if a somewhat inchoate one, 
of terms that express the more intimate phases of association to displace those of legal, political origin: King, Judge, and Lord of Hosts. . . Unless there is a movement into what I have called the third stage, fundamental dualism and a division in life continue. The idea of a double and parallel manifestation of the divine, in which the latter has superior status and authority, brings about a condition of unstable equilibrium. (LW 9:48-49)

In this last essay of $A$ Common Faith, Dewey suggests that the movement from religion to the antisupernaturalism of the religious attitude is a relatively simple, uncomplicated linear progression. ${ }^{14}$ Leaving religion is what happens when intelligence rules expectations. But Dewey knows the progression is not linear and neither is it simple. The impulse for realizing the religious function of the community emerges only as a reaction to a diremption in the experience of the individual. The realization of the religious function of experience involves conflict. In Dewey's inimitable way of saying it, "the social center of gravity of religion" has shifted from an incorporative living explanation to the defense of beliefs in light of scientific discovery (LW 9:41). "[A] kind of polite deference to the notion [of the supernatural] remains along with a concrete transfer of interest. The general mind is thus left in a confused and divided state. The movement that has been going on for the last few centuries will continue to breed doubleness of mind until religious meanings and values are definitely integrated into normal social relations" (LW 9:44). This "movement" that breeds doubleness of mind is the basis for Dewey's three stages of growth, from the assumption that man is evil and must be overcome by an external power, to the stage where natural values are elided with religious values and kept safe in supernatural vaults, to this third stage where value is seen for what it is - naturally available, fully productive of "religious" value, and needing no supernatural validation or protection.

The transition to the third stage is Dewey's ground for apologetic. This transition is what human intelligence seeks, where doubleness of mind is replaced with secure and meaningful practice. Attaining this stage, though, occurs only when corporate human action fully realizes its freedom by choosing its own authority-converting human association into a democratic community. Dewey focuses on the effect of overcoming religion as the means of perceiving progress toward the democratic community. From this perspective, his advocacy of this overcoming is an expression of care: "Criticism of the commitment of religion to the 
supernatural is positive in import. All modes of human association are 'affected with a public interest,' and full realization of this interest is equivalent to a sense of a significance that is religious in its function" (LW 9:53).

A nearly irresistible sense of religious progression emerges in $A$ Common Faith as Dewey moves from a beginning in naïve supernatural faith, through an articulation of the intelligent object of faith, in this last chapter, that makes it possible to reconnect with practice in "The Human Abode of the Religious Function." The proper domain of the religious function is the human community, but exercising this function depends on the transformation of individuals to the religious attitude and the stabilization of the object of faith. Dewey self-critically challenges this form of progression, though. The first line of this chapter reads, "In discussing the intellectual content of religion before considering religion in its social connections, I did not follow the usual temporal order. Upon the whole, collective modes of practice either come first or are more important" (LW 9:40). He is careful to make this qualification because his organic reflection on religion inverts the trajectory of Experience and Nature where social connections do precede intellectual content. A Common Faith constitutes a challenge to his understanding of the natural emergence of ideal action. Dewey is pressed to recover the priority of social relations as the ground of human transformation, although now this becomes a spiritual rather than a temporal priority. He argues that achieving the religious function of the democratic community results from the progressive impulse to overcome the "gospel of salvation" in which individuals are held by supernatural expectations. Achieving ideal action, at least in A Common Faith, depends on establishing religious overcoming as the common ground between the individual and the community. I think this is where Dewey makes his most explicit argument that the good of the community must overwhelm individual interest. Individuals must undergo a conversion to the community, and this requires the abandonment of supernatural religion.

In the previous section we noted that the religious function of seeking a transformation to a "whole" self makes the community possible, holding diverse acts of intelligence into a workable union as a gathered and gathering focus. Dewey seeks to describe the space between the gathered focus of the good of human association that intervenes in and directs behavior, and the gathering focus of human behavior emerging 
within all aspects of intelligent human behavior. The space between these two foci is where redirection of the community can occur. Dewey interjects the challenge of religious overcoming into this space as the principle of reorienting the direction of the community.

Implicit in this effort toward redirection is the realization that the authority that presently "holds" the community is different from the authority that "holds" individuals within the community. If there is no difference between these then there is no ground for an internal dialect that issues in progress. Dewey suggests that the prospect of a supernaturally funded reprieve from the limits of the finite power of individual life is still attractive, despite the problems it raises. Such a hope still holds many individuals. But the development in the community follows a hope that is focused on the adoption of the authority of science. This is the root of the change in the "social center of gravity of religion." Aligning the prospects of individuals and the community is the primary exhortative work of this essay. Dewey is not responsible for generating this conflict or this content. He can, however, point out the disjunction and how it may be resolved. To accomplish this, he must persuasively describe anew the individual in terms of an aspect of the community's progress toward good, and second, he must describe the community's good as a collation of the gains made by the intelligent practice of individuals. Religious overcoming makes sense of the individual as a rejection of the "hold" of supernatural authority in deference to the community. This third essay is necessary to build the common ground between individual and community for this transition to occur. Overcoming the desire for individual salvation, then, is not a function of the power of the individual's will; it is the test of the reality of the community.

The outcome will not be a gospel of salvation but it will be in line with that pursued, for example, in matters of disease and health. The method if used would not only accomplish something toward social health but it would accomplish a greater thing; it would forward the development of social intelligence so that it could act with greater hardihood and on a larger scale.

Transport into the realm of human life where intelligence has meaning beyond overcoming "this or that" individual concern means, in essence, a complete reversal of the hope for a "gospel of salvation." Such a reversal is a sign that the authority of the community has attained its proper place. 
It is not clear whether Dewey thinks such a reversal of hope must be advocated - do this! - or merely described, as a condition that follows a preceding condition. If Dewey takes the role of advocacy, which I think he does, then $A$ Common Faith is more like a sermon on the "calling to which we have been called" than a philosophical treatise that presents "what is." Dewey vacillates between these poles, and because he is unclear about his purpose this text occasionally escapes his control. ${ }^{15}$

Between the role of preacher and philosopher, however, Dewey manages to articulate the fact that the conversion of authority is the great good, the natural good, of human life. Only such a conversion of the whole context of practice can counteract the "social reign of accident" in which the supernatural is trusted to accomplish our aims. Religion, as the communal reflection of this trust, is the primary target in getting around this limiting dependence on the supernatural. But the trust that religion still incites in people that depends on little or no evidence, that constrains individuals to refine their practice in accord with an ideal community, that is carried from generation to generation through the passionate commitment of men and women-this trust must be collected together by Dewey into the conversion of authority for the community. Dewey's appeal is that individuals must be religious about overcoming religion.

Were men and women actuated throughout the length and breadth of human relations with the faith and ardor that have at times marked historic religions the consequences would be incalculable. To achieve this faith and élan is no easy task. But religions have attempted something similar, directed moreover toward a less promising object-the supernatural. It does not become those who hold that faith may move mountains to deny in advance the possibility of its manifestation on the basis of verifiable realities. There already exists, though in a rudimentary form, the capacity to relate social conditions and events to their causes, and the ability will grow with exercise. There is the technical skill with which to initiate a campaign for social health and sanity analogous to that made in behalf of physical public health. Human beings have impulses toward affection, compassion and justice, equality and freedom. It remains to weld all these things together. (LW 9:54-55)

What Dewey finds necessary for this description of the religious function of experience is an ultimate disjunction. The content he establishes for the "religious attitude" is a negative content: it must be all things 
appearing in human practice, but it cannot be religion. The authority Dewey desires for establishing the power of intelligence can be discovered only in this opposition to the supernatural. Dewey is not an aggressive atheist, but he is an aggressive naturalist (read "antisupernaturalist"). Whether this is opposition or positive criticism, Dewey's emphasis comes down to the authority that moves individuals to act in light of ideal ends and the community gathered around these ends. The success of his description of the religious function stands on the claim that the authority of supernatural responsibility cannot move individuals in the same productive ways as the absence of that supernatural responsibility. I wonder, however, at his grounds for saying this. What sort of community is he trying to evoke, for clearly he is trying to evoke one. What would a human community completely absent of supernatural expectations mean? ("Ask Zarathustra," a friend recommends. Another time, another place.) We have no way of anticipating this community, and even if we could, how would it not be completely discontinuous with the whole history of human social existence?

I do not think Dewey wants to fashion a new community. I think he wants to evoke a "formerly supernaturally religious" community out of the present one. Like a prophet or a reformer he is calling his community to leave the false god of "God" and serve only the true and living "God" of the democratic community.

I cannot understand how any realization of the democratic ideal as a vital and moral spiritual ideal in human affairs is possible without surrender of the conception of the basic division to which supernatural Christianity is committed. Whether or no we are, save in some metaphorical sense, all brothers, we are at least all in the same boat traversing the same turbulent ocean. The potential religious significance of this fact is infinite.

But this democratic realization will always remain derivative on the supernatural community since he cannot deny that the urge for the religious attitude comes bound up with it. Dewey confirms that the democratic community will always carry its opposite, supernatural religion, with it. Other insistent naturalisms, like the "death of God" theology, also work the opposite of what they intend, even as militant theisms are most productive of their counters in atheism. ${ }^{16}$ Using religion's language to counter its strength, and attempting to emancipate its good from its traditional authority, involves Dewey in a set of problems that exceeds his control. He desires the power supernaturalism extends over the lives of 
its adherents. He is jealous of that power, and he would be wiser in its use, better able to aim the motive force of the religious attitude toward truly productive ends. Prometheus would be so bold.

Although Dewey claims that he is describing what has always been the "common faith" of mankind, the conclusion of this third essay comes across as a performative exercise. Dewey is attempting to speak this community into existence. John Smith finds a similar point in Dewey's use of the term nature. Dewey claims that nature is "all there is," and thus it does not entail a principle of difference. But if there is no difference, Smith says, nature is a gratuitous term. Smith's point can be extended to say that Dewey's naturalism is not just an effort to discover a complete description of "what is"; it is a platform for making a criticism. ${ }^{17}$ Dewey's naturalism is unclothed in $A$ Common Faith as a fundamental critique of supernaturalism. This text is a recapitulation of Dewey's long struggle to explain his dramatic transition from the authority of the supernatural to the authority of democracy. This opposition orients his pragmatism. His willingness to confront this opposition, internal to his thinking, funds his role as America's leading naturalist, and his leadership stands on his ability to cut across boundaries otherwise respected. Dewey throws himself into the balance as the living image of the personal conversion he attempts to encourage in this concluding essay of $A$ Common Faith: "Ours is the responsibility of conserving, transmitting, rectifying and expanding the heritage of values we have received.... Here are all the elements for a religious faith that shall not be confined to sect, class, or race. Such faith has always been implicitly the common faith of mankind. It remains to make it explicit and militant" (LW 9:58).

The "salvation" of Dewey's pragmatism depends on the success of speaking the democratic community into existence. The religious progression that structures this "common faith" needs a push. Dewey whispers confident words in the ears of his auditors; "finish the good work that was begun in you." If his speech does produce a community it would not have a supernatural origin but a basis in the method of science. The religious attitude emerging from this community, propelling it toward the discovery of deeper and richer associations, affecting the shift of individual wills toward this content as an image of wholeness, would confirm that Dewey's faith in the common faith of mankind is not vanity. 


\section{RELIGIOUS OVERCOMING}

The common faith Dewey gives us is only possible by individuals overcoming religion. The natural origin of this conversion of the whole person from religion to the scientific choice of authority validates his hope for the evolving democratic community. Without such a conversion, Dewey's project fails descriptively and programmatically. Dewey needs the transition of religion to the religious attitude as a screen to complete his project.

Dewey's confession in A Common Faith is an example of a monumental overcoming of tradition by personal discovery, similar to what we have seen in Augustine and Edwards. In each of these cases the individual becomes the moment of significance for the community's transformation. This expectation exposes a peculiar limit to Dewey's pragmatism. How does the individual become held by the community in such a way that transformation is possible between them-the individual transforming the community and the community transforming the individual? Dewey's model suggests that the goal of transformation is establishing the continuity between individual and community, but in practice transformation seems to emerge in the disjunction between these. The individual is necessary to have substantial criticism of the community, and the community exposes the narrowness and the (ir)relevance of the individual. This marks a significant difference between Niebuhr and Dewey. For Niebuhr the question of social progress is twofold, overcoming the sinful rejection of responsibility and countering the force of the communal authority with an equally powerful authority. This is the reason Niebuhr sees the vital role of religion in social progress while Dewey sees the need for the church to lay aside its present method and take up the interests of society. ${ }^{18}$

Niebuhr's insight is a powerful check on Dewey's optimism. While Dewey's conversion to the religious attitude sheds light on the immanent aspects of transformation in both the individual and the community, he cannot fully explain the permanence of the destabilizing forces that produce the disjunction between supernaturalism and trust in the authority of science. Claiming these are both the products of nature is nominalistic, and such nominalism subverts inquiry, just as Peirce says it does. There is more going on in the interaction between religion and the religious than Dewey suggests. The impulse of the person to find 
religious ground is more than a desire for a formal character of a settled will. There is an urge to discover an appropriate content for the will. Dewey claims that this content is negative - the content of the will most apparent in A Common Faith is opposition to the authority of supernatural control. But to be genuinely communal this rejection has to arise within an actual communal shift. This is the most serious challenge to Dewey's description of faith. If the rejection of "the supernatural" for "the religious attitude" is made on the basis of some appearing good, some content, I do not think the "unity of ideal ends" in an imaginatively projected community can sustain the material transition in the community. I agree that the challenge to supernaturalism's hold on communal expectations is an organic occurrence, but I think there is some other content sought in this experience. Dewey's description fails to account for the origin of instability in individual and communal authority. The force within inquiry that resists idealistic claims of comprehensiveness is the realization of an absence of transformation rather than a discrete pursuit of growth. Supernaturalism represents this recognition of the absence of transformation for Dewey, for he often claims that in supernaturalism ideal ends are final and unmoving. Overcoming the absence of transformation is the core of Dewey's faith, and this is where his faith is genuinely a common faith. Dewey's remaining Protestantism is evident in the sense that no community or institution captures the enlivening demand for transformation emerging in individuals. $\mathrm{He}$ strives to collect this impulse into his argument for democracy, and in so doing he transforms it from an absence to a positive quality, growth. But if the growth of the democratic community becomes the telos of transformation that is fully realizable in experience, what further transformation would be necessary? Dewey produces an absolute and unquestionable verity that rivals any supernatural belief. ${ }^{19}$ But at the risk of repeating the error he criticizes, Dewey seeks to capture the vital engine of religious passion from religion for the democratic community. To accomplish this purpose he must overcome religion, personally and philosophically, and reconstruct the faith of his community.

The confidence in Dewey's analysis that enables him to locate a content that reorients the faith of the community is intoxicating. The evaluation of the practical ends of religion and religious faith are compellingly simple-if there is not a "good" end to religion, what is the good of religion? And the human community is all that can be anticipated as the 
ground for this good or any good. There are no metaphysical prizes that translate into reasonable ends for everyday living. This is the positive contribution Dewey makes. And locating the necessity of conversion of the individual to this appearing end extends that contribution. There can be no mistaking the commitment necessary for transforming our present experience into a better, richer, more humane experience. It does not happen by accident and it does not happen as a by-product of an orientation toward an abstract realm of rarified existence.

On the other hand, Dewey's religious vision produces precisely what he strives to avoid. In order to co-opt his democratic vision, the breadth of tradition must also be abandoned or, if not abandoned, reclaimed as purely symbolic in just the points that in our past have been the most productive of progression toward humanity. Dewey makes his religious faith into a radical disjunction between the philosopher and the common believer that cannot be overcome by qualification. Dewey excises his tradition, and all tradition, from the conception of the religious attitude and the conception of a democratic community. Faith, in Dewey's sense, is not the trust that the truth embedded in our tradition is sufficient for the next challenge. Faith is a kind of power that cannot be justified by observation nor restrained by tradition. Faith means excising one's self from the fabric of continuity of habits for the sake of what is beyond. Dewey seeks ground for a religious work that extends not from a passionate fidelity but from a passion for unfettered power. In this way, the democratic faith Dewey expounds becomes the twin of the abusive religious power he rejects. For Dewey's religious faith to be redeemed, it must be brought back into the tradition from which it emerges. This would truly amount to the religious overcoming Dewey seeks in order to secure the continuation of human progress in the social values that construct a better community.

\section{Notes}

1. Stephen Rockefeller, John Dewey's Religious Humanism (Columbia University Press, 1992); Robert J. Roth, American Religious Philosophy (Harcourt, Brace and World, 1967).

2. Daniel Rice, Reinhold Niebuhr and John Dewey: An American Odyssey (SUNY Press, 1993), 44. Horace Friess gives an account of a talk Dewey gave in 1930 that demonstrates both Dewey's reflection on religion as a mode of 
experience and not just an approach to a "common faith." Friess recounts Dewey's interest in the "hymnology, the prayers, the meditations" that move toward pertinencies of specific circumstances rather than the 'eternal verities' of religious dogma. Dewey says, "I would rather like to throw my emphasis tonight on that side of the importance of religion as a channel in which that kind of expression can flourish."

3. Robert Roth, American Religious Philosophy, 89.

4. See Bruce Kucklick's Churchmen and Philosophers: From Jonathan Edwards to John Dewey (Yale University Press, 1985) for an argument that Dewey never completely leaves the Calvinistic belief in the sovereignty of God or good.

5. Roth, American Religious Philosophy, 94.

6. Rice, Reinhold Niebuhr and John Dewey, 18-19.

7. Reinhold Niebuhr, Moral Man and Immoral Society (Scribners, 1960), 36.

8. Robert Westbrook, John Dewey and American Democracy (Cornell University Press, 1991), 426-427.

9. Michael Eldridge, Transforming Experience: John Dewey's Cultural Instrumentalism (Vanderbilt University Press, 1997), 23.

10. Eldridge, Transforming Experience, 50.

11. Martin Buber, I and Thou (Scribners, 1970), 30.

12. Larry A. Hickman, ed., Reading Dewey: Interpretations for a Postmodern Generation (Indiana University Press, 1998), 137.

13. James Campbell, Understanding John Dewey (Open Court, 1995), 103.

14. See, for instance, Robert Benne's Quality with Soul (Eerdmans, 2001) for an example of this description of Dewey from religious faith to a progressively liberal and idealized faith.

15. Richard Bernstein, John Dewey (Washington Square Press, 1966), 196.

16. Michael Buckley, At the Origins of Modern Atheism (Yale University Press, 1987), 36.

17. John Smith, Reason and God (Yale University Press, 1961), 114.

18. Niebuhr, Moral Man and Immoral Society, 62:"Religion is always a citadel of hope built on the edge of despair. But the same absolutism which drives them to despair, rejuvenates their hope. In the imagination of the truly religious man the God, who condemns history, will yet redeem history." Dewey states, "The surrender of claims to an exclusive and authoritative position is a sine qua non for doing away with the dilemma in which churches now find themselves in respect to their sphere of social action" (LW 9:55).

19. John Milbank, Theology and Social Theory: Beyond Secular Reason (Blackwell, 1991). 